\title{
DR. KING'S DREAM OF AFFIRMATIVE ACTION
}

\author{
David B. Oppenheimer*
}

\begin{abstract}
President Trump and Attorney General Sessions have decided to challenge affirmative action policies in higher education as a form of discrimination against white people. We should expect them to soon be citing Dr. King's 1 Have A Dream speech as evidence that Dr. King would be supporting their position if he were still alive. We should also expect them to propose that class-based affirmative action replace race-based affirmative action, and again cite Dr. King, as a supporter of remedies for poverty, regardless of race. Indeed, the contemporary debate about affirmative action increasingly pits those who support race-based affirmative action against those calling for class-based affirmative action, which is frequently described as a "color-blind" alternative. And in support of this alternative to raceconscious affirmative action, its proponents often invoke Dr. King as a supporter of color-blind affirmative action.

The truth is more complicated, and infinitely more interesting and instructive. While Dr. King dreamed of a time when racism - and thus race - would be irrelevant, he was an active supporter of both kinds of affirmative action-race-based and class-based. As a supporter of race-conscious affirmative action, he spent much of the last six years of his life actively promoting it, including the use of racial quotas in employment. Specifically, from 1962-68 Dr. King orchestrated and implemented "Operation Breadbasket," a civil rights boycott campaign that demanded racial quotas through the employment of Black American workers in proportion to their number in a workforce, neighborhood or city. With regard to class-based affirmative action Dr. King supported a massive war on poverty. In advocating for special benefits for poor Americans he sometimes used color-blind language and pointed out that it would benefit poor whites as well as poor Blacks, while at other times he justified it as an example of the kind of reparations to which Black Americans were entitled under the equitable remedy of restitution for unpaid wages. To those who invoke Dr. King as a supporter of color-blindness and an opponent of race-conscious affirmative action, and to those who advocate race-conscious affirmative action over class-based affirmative action, nearly fifty years after his murder Dr. King's voice continues to send us an important message: we do not need to choose one approach over the other; we can and should do both.
\end{abstract}

\section{TABLE of CONTENTS}

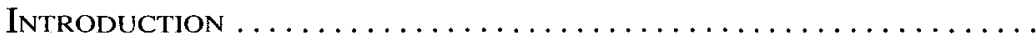

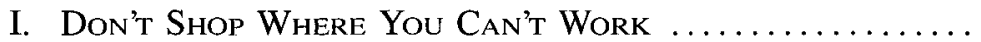

II. Rev. Leon Sullivan \& the Selective Patronage

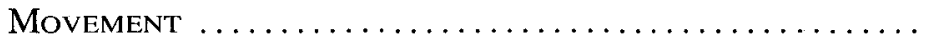

III. Dr. King's Trip to India: “I am an Untouchable" ......

* Clinical Professor of Law, University of California, Berkeley. I am grateful to Doug Avila and Edna Lewis from the Berkeley Law Library, and to my Berkeley Law research assistants Astrid Ackerman, Alejandro Barrientos, Veerangna Bhandari, Rachel Corrigan, Taqwa Tayseer Elhindi, Rachel Foodman, Lilliana Paratore, Candice Shikai, Audree Steinberg, Farrah Vazquez, Vidya Venugopal and Gregory Washington for their invaluable assistance. 


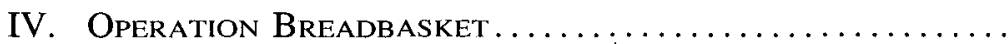

V. Dr. King's support of Class-Based Affirmative Action to Defeat Poverty and Racial Inequality ............

VI. Why Affirmative Action? Dr. King's Legal Theory of

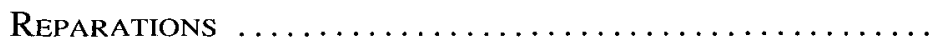

VII. Dr. King, Latinx Leaders, and California's Battle over Proposition 209 ............................

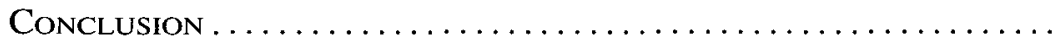

\section{INTRODUCTION}

The legitimacy of race-conscious affirmative action is among the most contentious issues of law and policy in American society. Discussions of affirmative action are often heated, in part because the very meaning of the term is contested. What are we arguing about when we try to discuss affirmative action? For some, affirmative action means racial and gender quotas. ${ }^{1}$ For others, it means proportional representation, preferences, tiebreakers, goals, aspirations, outreach/recruiting efforts, mentoring, monitoring, selfexamination, or affirmative anti-discrimination efforts. ${ }^{2}$ Affirmative action policies are used, and used differently, in employment hiring and promotion, college and university admissions, procurement of goods and services, and oversight of government contracting. Affirmative action can be a court-ordered remedy, a voluntary policy adopted by private or public entities, a legislative or administrative mandate, or a professional best practice. Discussions of affirmative action sometimes frame the question as one of Constitutional law, and other times as a question of administrative law, social/ political theory, morality, policy or politics. As used in public policy discussions, legal arguments and political debates, it is usually tied to race, ethnicity or gender, but it can also be used to describe policies to assist military veterans, or the poor, or for that matter the rich, as with legacy admissions to elite private colleges.

Although demands for policies conferring benefits based on race-based proportional representation have been around for many years, ${ }^{3}$ the use of the term "affirmative action" to describe such policies dates only to the $1960 \mathrm{~s}^{4}$

${ }^{1}$ While racial and gender quotas are rare in the United States, they are common in most parts of the world. See David B. Oppenheimer, Sheil.a R. Foster, Sora Y. Han \& Richard T. Ford, Comparative Equality and Anti-Discrimination Law 220-275 (2d ed. 2017); Julie Suk, Quotas and Consequences: A Transnational Re-evaluation, in PHLOSOPHICAL FounDations of Discrimination Law 228-249 (Deborah Hellman \& Sophia Moreau eds., 2013).

${ }^{2}$ See David B. Oppenheimer, Understanding Affirmative Action, 23 Hastings Const. L.Q. 921(1996) (describing multiple models of affirmative action); David B. Oppenheimer, Distinguishing Five Models of Affirmative Action, 4 BERKELEY WOMEN's L.J. 42 (1989) (same).

${ }^{3}$ See infra Section II.

${ }^{4}$ In its contemporary meaning, its first use in print may have been a NY Times article dated October 13, 1960 that quotes Harold Stevens, the first Black American to be appointed an appellate judge in New York, calling for "affirmative action in civil rights." See Boston Tea Party and Civil Rights Linked, N.Y. Times, Oct. 13, 1960, at 73. 
The term itself has been part of the legal lexicon since the 1930s, when it was used to describe the remedies available under the National Labor Relations act. ${ }^{5}$ It became a legal term of art in the anti-discrimination context in 1961, when it was used in an Executive Order governing government contracting issued by President Kennedy. ${ }^{6}$

With regard to college and university admissions, the contemporary debate about affirmative action increasingly pits those who support race-based affirmative action against those calling for class-based affirmative action, which they frequently describe as a "color-blind" alternative. Two leading advocates for class-based affirmative action are Georgetown University law professor Sheryll Cashin, ${ }^{7}$ and Century Foundation senior fellow Richard D. Kahlenberg. ${ }^{8}$ Michael Bloomberg has launched an initiative to help lowincome high achieving students, regardless of race, attend top colleges. ${ }^{9}$.

In response, Berkeley Law senior fellow Richard Rothstein has argued that race-based affirmative action serves important social purposes that would not be served by substituting, or adding, class-based affirmative action. ${ }^{10}$ By contrast, Columbia University President Lee C. Bollinger argues that we can (and should) have both."

Cashin draws support for her position from the success of the Texas $10 \%$ plan $^{12}$ and the Sciences-Po zones of economic opportunity plan, ${ }^{13}$ both of which use place-based affirmative action as a substitute for race-based

${ }^{5}$ See National Labor Relations Act, 29 U.S.C. $\$ 160(c)(2012)$ (The "Board shall . . take such affirmative action . . . as will effectuate the policies of this Act").

${ }^{6}$ See Exec. Order No. 10965, 26 Fed. Reg. 1977 (March 6,1961) (The contractor will take affirmative action to ensure that applicants are employed, and that employees are treated during employment, without regard to their race, creed, color, or national origin).

${ }^{7}$ See generally Sheryli. Cashin, Place, Not Race: A New Vision of Opportunity in AMERICA (2014); Sheryll Cashin, Place, Not Race: Affirmative Action and the Geography of Educational Opportunity, 47 U. MrCH. J.L. ReForm 935 (2014).

${ }^{8}$ See Richard D. Kahlenberg, In Defense of Class-Based Affirmative Action, THE CENTURY Found. (May 31, 2013), https://tcf.org/content/commentary/in-defense-of-class-basedaffirmative-action, archived at https://perma.cc/2LES-E9J9.

${ }^{9}$ See Press Release, Bloomberg Philanthropies, Bloomberg Philanthropies Launches New Initiative to Help High-Achieving, Low- and Moderate- Income Students Apply to and Enroll in Top Colleges and Universities (2014), https://www.bloomberg.org/press/releases/bloomberg-philanthropies-launches-new-initiative-help-high-achieving-low-moderate-income-students-apply-enroll-top-colleges-universities/, archived at https://perma.cc/6EBZ-V9H; see also, David Leonhardt, Make Colleges Diverse, N.Y. TIMEs, Dec. 13, 2016, at Al.

${ }^{10}$ See Richard Rothstein, The Colorblind Bind: Focusing College-Student Recruitment on Poor Neighborhoods Can Overlook Middle-Class African Americans Entitled to Affirmative Action, THE AM. ProsPeCT (June 22, 2014), http://prospect.org/article/race-or-class-future-affirmative-action-college-campus, archived at https://perma.cc/TUX7-D3Y9; Richard Rothstein \& Sheryll Cashin, Affirmative Action, Race or Class: An Exchange, THE Am. Prospect (August 1, 2014), http://prospect.org/article/affirmative-action-race-or-class-exchange, archived at https://perma.cc/F4N9-A6WC.

${ }^{11}$ See Lee C. Bollinger, The Real Mismatch: The Supreme Court Should not Force Universities to Trade Affirmative Action for Socioeconomic Diversity; Schools Can Have Both, SLATE (May 30, 2013), http://www.slate.com/articles/news_and_politics/jurisprudence/2013/ 05/supreme_court_and_affirmative_action_don_t_make_schools_trade_race_for_class.html, archived at https://perma.cc/8PJL-PQU.

${ }^{12}$ See Fisher v. Univ. of Tex., 136 S. Ct. 2198 (2016) [hereinafter Fisher II] (approving a combination of place-based and race-based affirmative action). 
affirmative action. But as Justice Ginsberg noted regarding the Texas plan, it provided diversity only because of residential segregation, and was thus a race-conscious plan that only an ostrich could view as race-neutral. ${ }^{14}$ And the Texas plan also uses race-based affirmative action to supplement its place-based plan, a position the Supreme Court approved in Fisher II. ${ }^{15}$ Rothstein argues that the Cashin approach leaves behind too many middle class Black students who still suffer substantial damage from racial discrimination, both in the form of present effects of past discrimination, and through continuing discrimination. ${ }^{16}$ The experience at the University of California, Berkeley, Rothstein's institution (and mine), bears this out. Black undergraduate enrollment at Berkeley has dropped from $7.8 \%$ in 1997 (the last year Berkeley used race-conscious affirmative action) ${ }^{17}$ to $2.8 \%$ today. ${ }^{18}$

Kahlenberg points to Berkeley as a success story for class-based affirmative action. Thirty-four percent of Berkeley students receive Pell grants, a common measure of lower socioeconomic class. ${ }^{19}$ By comparison, at Yale only $12 \%$ of the students receive Pell grants. ${ }^{20}$ In 2009 UC Berkeley had more students receiving Pell grants than the entire Ivy League combined. ${ }^{21}$ But Rothstein argues that while socioeconomic diversity and social mobility are worthy goals, overcoming the legacy of racism and its continuing manifestation is a far more compelling justification. Bollinger's answer is to do both. Kahlenberg is skeptical. His response is that while some schools, including Columbia and Amherst, have successfully used both race and class, most will not, finding race-based affirmative action seductively easier. ${ }^{22}$

While I have found no instance of Rev. Dr. Martin Luther King, Jr. ever using the term "affirmative action," ${ }^{, 23}$ forty-eight years after his assassina-

${ }^{13}$ See Daniel Sabbagh, Affirmative Action at Sciences Po, 20 Fr. Pol., Culture And Soc'Y, no. 3, Fall 2002, at 52-58 (describing place-based affirmative action at the Institut D'Etudes Politiques De Paris).

${ }^{14}$ See Fisher v. Univ. of Tex., 133 S. Ct. 2411 (2013) [hereinafter Fisher I] (Ginsburg, J., dissenting).

${ }_{16}^{15}$ See Fisher II, supra note 12.

${ }^{16}$ See Rothstein, supra note 10; see generally, Brown er AL., White-Washing Race: THE MYTH of A COLor-Blind SOCIETY (2003).

${ }^{17}$ See Sahil Chinoy, Breaking Down the Status of Affirmative Action at UC Berkeley, Daily CALIForniAn (June 29, 2016), http://projects.dailycal.org/affirmative-action, archived at https://perma.cc/RM33-4CA9.

${ }^{18}$ See UC Berkeley Fall Enrollment Data, U.C. BERKELEY, http://opa.berkeley.edu/ucberkeley-fall-enrollment-data, archived at https://perma.cc/7N33-C86L (last visited Dec. 18, 2017).

${ }^{19}$ Kahlenberg, supra note 8.

${ }^{20}$ See Frank Bruni, An Admissions Surprise from the Ivy League, N.Y. Times (Oct. 17, 2015), https://www.nytimes.com/2015/10/18/opinion/sunday/an-admissions-surprise-from-theivy-league.html?_r $=0$, archived at https://perma.cc/L9FJ-HT48.

${ }^{21}$ See Nicole Ely, UC Berkeley Chancellor Keeps Hope Alive Despite Budget Challenges, NEw AM. MEDIA (Feb. 21, 2009), http://talk.collegeconfidential.com/financial-aid-scholarships/656887-uc-berkeley-has-more-students-on-pell-grants-than-all-the-ivy-league-schoolsput-toge.html, archived at https://perma.cc/FMP7-28WT.

${ }^{22}$ Kahlenberg, supra note 8.

${ }^{23}$ A search of the terms "Martin Luther King" and "affirmative action" in the New York Times archives reveals no hits prior to his murder. 
tion his name is often invoked in the affirmative action debate by opponents of race-based affirmative action, who cite Dr. King's "I Have a Dream" speech as evidence that he supported "color-blind" policies, and thus presumably would have opposed race-conscious affirmative action. ${ }^{24}$ But when we examine the historical record it is clear that while Dr. King dreamed of a time when racism - and thus race - would be irrelevant, he was a supporter of both of these forms of affirmative action. On the one hand, he spent much of the last six years of his life actively promoting what we would describe today as race-conscious affirmative action, including the use of racial quotas in employment. Specifically, from 1962-68 Dr. King orchestrated and implemented "Operation Breadbasket," a civil rights boycott campaign that demanded employment quotas for Black American workers based on their numbers in a workforce, neighborhood or city. ${ }^{25}$ Yet on the other hand, with regard to class-based affirmative action, Dr. King supporte"d

${ }^{24}$ See Denise M. Bostdorff and Steven R. Goldzwig, History, Collective Memory, and the Appropriation of Martin Luther King, Jr.: Reagan's Rhetorical Legacy, 35 PRESIDENTIAL Stud. Q., no. 4, Dec. 2005, at 661-90; Paul Rockwell, The Right Has A Dream: Martin Luther King as an Opponent of Affirmative Action, FAIRNESS AND ACCURACY IN REPORTING (May 1, 1995), http://fair.org/extra/the-right-has-a-dream/, archived at https://perma.cc/H5PX-ZB4J; John Blake, Why Conservatives Call MLK Their Hero, CNN (Jan. 19, 2013, 11:24 PM), http:// www.cnn.com/2013/01/19/us/mlk-conservative/index.html, archived at https://perma.cc/ LWB4-VLE3; see, e.g., William J. Bennett, Civil Rights is the GOP's Mission: California's Prop. 209 is a National Bellwether for Restoring Dr. King's Dream of a Colorblind Americä, L.A. TIMEs (Aug. 12, 1996), http://articles.latimes.com/1996-08-12/local/me-33453_1_civilrights-movement, archived at https://perma.cc/E3HV-WFLD; Elizabeth Olson, Civil Rights Activists Locked Horns with William Bradford Reynolds, UnITED PRESS INTN'L (Aug. 9, 1982), https:/www.upi.com/Archives/1982/08/09/Civil-rights-activists-locked-horns-with-WilliamBradford-Reynolds/1347397713600/, archived at https://perma.cc/9V58-KJ8U (quoting Assistant Attorney General for Civil Rights under President Reagan citing Dr. King as an opponent of race-based affirmative action); Roger Clegg, Opinion, Martin Luther King vs. Role Model Nonsense, INSIDE Higher EDUC. (Jan. 19, 2006), https://www.insidehighered.com/views/2006/ 01/19/martin-luther-king-vs-role-model-nonsense, archived at https://perma.cc/D4MH-95XQ; Ward Connerly, Senator Obama, You're No King, NAT'L Rev. (Aug. 28, 2008, 7:00 AM) at http://www.nationalreview.com/article/225461/senator-obama-youre-no-king-ward-connerly, archived at https://perma.cc/KRD6-PLKN; Dave Lesher, Prop 209 Backer Defends Use of King in Ad, L.A. Times (Oct. 24, 1996), http://articles.latimes.com/1996-10-24/news/mn57212_1_king-s-vision, archived at https://perma.cc/D6FF-YSDX (describing plan to use Martin Luther King, Jr.'s "I Have a Dream" speech in television advertisements supporting California's Proposition 209 which, upon passage in 1996, prohibited public institutions from engaging in affirmative action based on race, national origin, ethnicity or sex); see generally, David E. Fitzkee, The Final Arbiter: Supreme Court Jurisprudence and the Trend Toward Conservatism in Affirmative Action in America, in 1 Controversies in Affirmative Action 113, 121-22 (James Beckman ed., 2014) (summarizing the conflicting views on the correct interpretation of Dr. King's "I Have a Dream" Speech); Clanence Page, Showing My Color: ImpoltTe EssAYS ON RACE AND IDENTITY 5 (1996) (suggesting that the words of Dr. King have been perverted to support the colorblind approach to law); Cornel West, Why I'm Marching in Washington, in Bl.ack Men on Race, Gender, and Sexuality: A Critical Reader 22, 26 (Devon W. Carbado ed., 1999) (criticizing those "who cheaply invoke Dr. King's words even as they kill the substance and spirit of his radical message."); Bruce Fein, Diversity, Why Worry?, LEGAL Times, Nov. 18, 1996, at B15 (arguing that Dr. King "poignantly voiced" that "[m]ost people yearn for treatment as an individual, warts and all, neither boosted by the privileges. . nor degraded by irrelevancies, such as gender or race").

${ }^{25}$ See infra Sections II-V. 
a massive war on poverty. ${ }^{26}$ In advocating for special benefits for poor Americans he sometimes used color-blind language and pointed out that it would benefit poor whites as well as poor Blacks, while at other times he justified it as an example of the kind of reparations to which Black Americans were entitled under the equitable remedy of restitution for unpaid wages.

Following this introduction, in Parts I-III of this article I describe Dr. King's support for affirmative action quotas in Operation Breadbasket and explore the origins of his position. I point to three primary influences on Dr. King's support for quotas. First, Dr. King looked to the long line of historically successful boycott campaigns in the 1920 s-40s, which operated under the slogan "Don't Shop Where You Can't Work" and called for boycotts of business establishments that did not hire Black workers in proportions reflective of the Black community at large. These boycotts provided a blueprint for the boycotts Dr. King organized in Montgomery, Birmingham and elsewhere, culminating in Operation Breadbasket. Second, Dr. King was inspired by the work of Rev. Leon Sullivan, an activist minister from Philadelphia who organized a "Selective Patronage" boycott campaign, itself inspired by the "Don't Shop Where You Can't Work" campaigns. Rev. Sullivan worked with Dr. King in replicating his Philadelphia boycotts in Operation Breadbasket. Third, at the invitation of Prime Minister Nehru and motivated by a desire to study Gandhian principles, Dr. King traveled to India in 1959. While there, he was exposed to the Indian Constitutional system of caste-based quotas in employment and education ("reservations"), and was highly impressed by their effectiveness. These three influences gave rise to Dr. King's organization of boycotts that demanded proportional hiring of Black employees in Black neighborhoods.

In Part I, I discuss the "Don't Shop Where You Can't Work" campaigns that began in the 1920s. During this time, employment discrimination against Black Americans was required by law in parts of the U.S., was widely practiced elsewhere, and was either compelled or permitted by law everywhere. While some White employers voluntarily hired Black workers throughout U.S. history, it was in the 1920s, as the modern Civil Rights Movement was beginning to find its voice, that civil rights activists began to focus on the demand that private White employers hire Black workers, and these demands were commonly (and controversially) framed as demands for proportional hiring, or quotas. The demands were often made in the form of boycotts organized against employers who provided goods and/or services in Black neighborhoods but refused to hire Black workers, with boycott organizers frequently carrying signs exhorting Black shoppers, "Don't Shop Where You Can't Work!" From the 1920s through the 1960s, these campaigns played an important role in the Civil Rights Movement.

The boycott campaigns also gave rise to the critical legal question of when such boycotts could be enjoined as illegal restraints of trade. In two

${ }^{26}$ See infra Section VI. 
rarely discussed early decisions on affirmative action, the Supreme Court held that boycotts supporting non-discrimination were lawfully protected, but that boycotts supporting proportional hiring were not.27 This distinction between non-discrimination and quotas continues to roil legal and policy discussions about civil rights. In the context of hiring by private employers, it was resolved in the 1964 Civil Rights Act, where Congress elected to neither prohibit nor require hiring quotas, and in two decisions by the Supreme Court upholding the compromise, within proscribed limits. ${ }^{28}$

In Part II, I discuss the second influence on Dr. King's support for affirmative action quotas: the work of Rev. Leon Sullivan during the late 1950s. Rev. Sullivan organized the "Philadelphia Selective Patronage" Movement, itself inspired by the "Don't Shop Where You Can't Work" campaigns, that sought to radically alter the way in which private Philadelphia employers hired Black American employees. In 1962 Dr. King learned of Rev. Sullivan's work and invited him to come to Atlanta to help organize Dr. King's employment quota boycott program, Operation Breadbasket.

In Part III, I discuss the third influence on Dr. King's support for affirmative action quotas, his 1959 trip to India. Dr. King traveled to India at the invitation of Prime Minister Nehru, motivated by a desire to study Gandhian principles. While there, he was exposed to the Indian Constitutional system of caste-based quotas in employment and education ("reservations"), and was highly impressed by their effectiveness. In the nine remaining years of his life, Dr. King often spoke of the Indian Constitutional reservations systems with admiration, and as an example of how India was doing more than the United States to address the problem of racial inequality.

Then, in Part IV, I discuss how these three threads - the "Don't Shop Where You Can't Work" campaigns, the work of Rev. Leon Sullivan, and Dr. King's trip to India - inspired Dr. King to develop Operation Breadbasket, his boycott/quota program, first in Atlanta and then nationally. By the mid-late 1960s, Dr. King was trumpeting the success of this national boycott movement in creating many thousands of jobs for Black Americans throughout the country.

In Part V, I discuss Dr. King's support of class-based approaches to remedying racial inequality. I focus on Dr. King's support for affirmative action-type programs that address the problem of poverty. In advocating for special benefits for poor Americans he sometimes used color-blind language

${ }^{27}$ See generally New Negro Alliance v. Sanitary Grocery Co., 303 U.S. 552 (1938) (picketing for non-discrimination is protected activity); Hughes v. Superior Court, 339 U.S. 460 (1950) (picketing for proportional representation is not protected activity).

${ }^{28}$ See 42 U.S.C. $\$ 2000$ e(2)(j) (2012) (Nothing contained in this subchapter shall be interpreted to require any employer to grant preferential treatment to any individual or to any group because of the race of such individual or group on account of an imbalance) (emphasis added); Steelworkers v. Weber, 443 U.S. 193 (1979) (use of racial quotas for promotion permitted under limited circumstances); Johnson v. Transp. Agency of Santa Clara Cty., 480 U.S. 616 (1987) (gender preferences permitted under limited circumstances); see also, David B. Oppenheimer, The Disappearance of Voluntary Affirmative Action from the U.S. Workplace, $24 \mathrm{~J}$. POVERTY AND SOC. JUST., no. 1, 2016, at 40-42. 
and pointed out that it would benefit poor whites as well as poor Blacks, while at other times his focus was on Black Americans.

In Part VI, I will discuss Dr. King's justification for affirmative actiontype programs that focused on remedying racial inequality. Though Dr. King is not commonly associated with the movement for reparations, it is the principle that best describes his views. From the forgotten language of his 1963 I Have A Dream speech, to his 1964 post-Birmingham book Why We Can't Wait, to his 1967 testimony before the National Advisory Commission on Civil Disorders (the "Kerner Commission"), Dr. King frequently justified race-conscious programs to aid Black Americans on a theory of reparations, arguing that Black Americans were entitled to reparations under the equitable remedy of restitution for unpaid wages.

In Part VII, I discuss Dr. King's influence on Latinx leaders in the Civil Rights movement and later, on California's battle over Proposition 209. As Dr. King devoted his work to combatting poverty, regardless of race, ethnicity or national origin, he reached out to César Chávez, the leader of the United Farm Workers and a celebrated leader within the Latinx community-whom King described as his "brother[] in the fight for equality." 29 Dr. King hoped to work closely with Chávez on the Poor People's Campaign. Unfortunately, his life was cut short by an assassin's bullet before they had the opportunity to work together. But throughout this period as Dr. King embraced his campaign against poverty for all Americans regardless of race or ethnicity, he simultaneously continued to pursue the work of operation breadbasket, focusing on demands for job quotas for Black Americans under the threat of boycotts.

A generation after Dr. King's assassination, California became ground zero in the fight over affirmative action. An anti-affirmative action group proposed the California Civil Rights Initiative - or Proposition 209 - to ban affirmative action in public education, contracting and employment. They used Dr. King and the excerpt from his I Have A Dream speech as the centerpiece of their successful campaign. Among those who took a leading role in fighting against the initiative were the Latinx leaders of California in education and politics, including labor and civil rights activist Dolores Huerta and attorneys from the Mexican American Legal Defense and Education Fund (MALDEF).

I conclude that the unifying theme in Dr. King's advocacy was inclusiveness of all potential remedies. When we examine the body of his work, and particularly his writings, sermons, speeches and public testimony, this becomes clear. Here again, if we examine the less-often cited portion of his iconic 1963 I Have A Dream speech, where he called for reparations; his 1964 book "Why We Can't Wait" and his 1965 Independence Day sermon at his Atlanta church, where he invoked Indian affirmative action ("reserva-

${ }^{29}$ Telegram from Martin Luther King, Jr. to Ceasar Chaves [sic] (Sept. 19, 1966), http:// kingencyclopedia.stanford.edu/encyclopedia/documentsentry/telegram_to_cesar_chavez/index .html, archived at https://perma.cc/L6S8-VKVS. 
tions") and called for what today we would call affirmative action; and his 1967 testimony before the Kerner Commission, where he invoked Indian reservations and called for reparations and race-based affirmative action, what emerges is a powerful call for both forms of affirmative action being debated today: race-based and class-based. Any assertion that Dr. King was an opponent of race-conscious affirmative action must rely solely on a single phrase in a single speech, and avoid his long-standing commitment to raceconscious remedies in his speeches, writings and - most importantly - his actions. But neither should we conclude that he opposed class-based approaches to affirmative action; he supported both forms, to be used in tandem.

\section{Don't Shop Where You Can't Work}

The 1920 s were an "age of prosperity" for many urban White Americans, as the post-World War I boom created new jobs and opportunities in the growing industrial cities. Industrial production rose 70\% between 1922 and 1928 , and by the end of the decade nearly half the American population owned automobiles. ${ }^{30}$ The twenties were the first decade that the urban population exceeded the rural population, ${ }^{31}$ as America was being transformed into a country of cities. But rural poverty was a persistent problem, as commodities prices fell, forcing an increasing number of people, White and Black alike, from their farms.

For Black Americans, the twenties were a period of great hardship. Membership in the Ku Klux Klan reached its zenith at the four million mark (at a time when the entire U.S. population was only a little over one hundred million people). From the records of the Tuskegee Institute, we know that at least 281 Black Americans were lynched between 1920 and 1929.32 A majority of Black Americans still lived in the rural South, although the "Great Migration" of six million Black Americans from the South to the industrial North, Midwest and West had recently begun. ${ }^{33}$ In $1920,86 \%$ of the 10.4 million Black Americans lived in the South; by 1930 the Southern share of the Black population had dropped to $79 \%$ of 11.9 million. ${ }^{34}$ And between 1920 and 1930 the rural Black U.S. population was essentially unchanged,

${ }^{30}$ See The Prosperity of the Coolidge Era, LiBRARY of ConG., http://memory.loc.gov/ ammem/coolhtml/ccpres0l.html archived at https://perma.cc/C7PD-TAQD (last visited Nov. 10, 2017), citing Elizis Hawley, The Great War and the Search for a Modern Order (1922).

31 See U.S. Bureau of The Census, Historical Statistics of the United States: CoLONIAL TIMES TO 1957, at 14 tbl.A 195-209 (1960).

${ }^{32}$ See Lynchings: By Race and Year, Univ. of Mo. Kan. City Tuskegee Inst., http:// law2.umkc.edu/faculty/projects/ftrials/shipp/lynchingyear.html, archived at https://perma.cc/ 3PVS-DD2D (last visited Dec. 18, 2017); see also, W.E.B. Du Bois, The Shape of Fear, THE N. AM. REV., Summer 1926, at 291-303.

${ }^{33}$ See Isabei. Wilkerson, The Warmth of Other Suns: The Epic Story of America's Great Migration 9 (2010).

${ }^{34}$ See U.S. Bureau or 'THE Census, supra note 31, at 11-12 tbl.A 95-112. 
dropping from 6.9 million to 6.7 million, while the Black urban U.S. population climbed from 3.6 million to 5.2 million. ${ }^{35}$ Poverty for the millions of Black Americans living in the rural South was crushing, while conditions were only marginally better in the urban North and Midwest, where discrimination kept most Black Americans out of all but the most menial and lowpaying jobs.

But the 1920s was also the time of the Harlem Renaissance, the rise of the Black press, increasing enrollments in Black colleges, a rising Black middle class of small business owners, lawyers, dentists, physicians, and teachers catering to the growing urban Black population, and the growing strength of civil rights groups. The NAACP had been founded in 1909, and as the decade began it had over 90,000 members with some 300 local chapters ${ }^{36}$ and was beginning to make its voice heard. The National Urban League, founded the year after the NAACP, was also growing rapidly. The period in which there was little civil rights advocacy, often described as the "Nadir," was coming to an end. ${ }^{37}$

Into this mix of renaissance and repression came a renewed form of resistance, the boycott. It had been a popular form of protest against Jim Crow streetcar segregation in the late nineteenth century, ${ }^{38}$ and was now reborn in Chicago, and connected to a call for proportional representation racial quotas. As migration from the South grew, Chicago's Black population soared during the early years of the twentieth century. It rose from 44,000 in the 1910 Census to 109,000 in the 1920 census, and 233,000 in the 1930 Census. ${ }^{39}$ The Black newspaper the Chicago Whip, a newly formed

${ }^{35}$ U.S. Bureau of 'the Census, Statistical Abstract of the United States, 1940, at 20 tbl.21 (1941).

${ }^{36}$ See Oldest and Boldest, NAACP, http://www.naacp.org/pages/naacp-history, archived at https://perma.cc/Y7TY-L43T (last visited Dec. 18, 2017).

${ }^{37}$ The Nadir is commonly measured as the period between 1890 and 1915 or 1920 . Note that some historians now persuasively argue that during the Nadir a great deal of civil rights advocacy was occurring, leading to the movement that followed. See, e.g., Susan D. CarLe, Defining the Struggle: National Organizing for Racial Justice, 1890-1915 (2013); August Meier \& Elltiot Rudwick, Along the Color Line: Explorations in the BlaAck EXPERIENCE (1976); Glenda Elizabeth Gilmore, Somewhere in the Nadir of African American History, 1890-1920, Nat'L Humanities CTr. TeacherServe: Freedom's StTory, hitp://nationalhumanitiescenter.org/tserve/freedom/1865-1917/essays/nadir.htm, archived at https://per ma.cc/TU8H-TQLE (last visited Dec. 18, 2017).

${ }^{38}$ See Edjard Peeks, The Long Struggle for Black Power 268 (1971). Between the 1890 s and early 20 th century, there were several successful anti-segregation streetcar boycotts in Atlanta (1892-93), Augusta (1898), Savannah (1899), Jacksonville (1901), Montgomery and Mobile (1902), and Jacksonville and Pensacola (1905). See Meier and Rudwick, supra note 37, at 269. Additionally, during this period a series of lawsuits challenged segregated streetcars on legal grounds. See e.g., Pleasants v. N. Beach \& Mission R. Co., 34 Cal. 586, 586 (1868). Despite these efforts, beginning in the early 1900 s every State in the South passed streetcar segregation laws and all legal and civil forms of protest ultimately failed. Id. at 309.

${ }^{39}$ U.S. Bureau of the Census, [II Population, Reports by Sintes, with Statistics for Counties, Cities and other Civil Divisions, Alabama-Montana] Thrrteenth Census of the United States Taken in the Year 1910, at 512; U.S. Bureau of the Census, [III, Population, Composition and Characteristics of the Population by States] Fourteenth Census of the United States Taken in the Year 1920, at 261 (1922); U.S. Bureau of the Census, [III, Population, Reports by States, Composition and Charac- 
alternative to the long-established voice of the Black community, the Chicago Defender, had grown with the booming Black population. In 1929 the Whip called for a boycott of chain stores that would not hire Black workers, under the banner "Spend Your Money Where You Can Work."40 And it worked. With the support of major Baptist churches to supply picketers, the campaign targeted "five and dime" stores, the Wal-Mart's of the twentieth century, which were often located in Black neighborhoods but rarely hired Black Americans as clerks or white collar employees. Under the pressure of the boycott the stores started hiring Black employees. The campaign obtained jobs for an estimated 2,000 new Black employees in White-owned stores, ${ }^{41}$ and the movement spread.

By the early 1930s New York's Amsterdam News had taken up the call, changing the name of the campaign to "Don't Shop Where You Can't Work."42 Picketers first targeted Harlem's largest department store - Blumstein's - where a 12-day boycott led to the hiring of 25 Black workers. They then moved on to major chains like Woolworths and the A\&P grocery stores, again achieving success. Within a few years campaigns had begun in Oakland (1929), ${ }^{43}$ Toledo (1930), Cleveland (1931), Detroit (1932), Washington (1933), Baltimore (1933), Los Angeles (1934), Camden (1934), Richmond (VA) (1934), Columbus (1934), Cincinnati (1934), Philadelphia (1934), Boston (1934), and Atlanta (1935). ${ }^{44}$ NAACP co-founder W.E.B. DuBois endorsed the boycotts in a 1934 editorial in the NAACP's magazine, The Crises. ${ }^{45}$

In 1938 in New York, the boycott campaigns were revived under the leadership of A. Philip Randolph, president of the most important Black labor union in the country, the Brotherhood of Sleeping Car Porters, and the Rev. Adam Clayton Powell, Jr., then the assistant pastor of Harlem's large and important Abyssinian Baptist Church. ${ }^{46}$ They persuaded Consolidated Edison, New York's major electric utility company, to begin hiring Black workers in white-collar jobs; convinced New York Telephone to staff its entire Harlem office with Black workers, including a Black manager; got two

teristics of the Population by States, Alabama-Montana] Fifieenth Census of the United States TAKen in the Year 1930, at 628 (1932).

${ }^{40}$ PEeks, supra note 38, at 268-89; see also, Christopher Manning, African Americans, THE ELECTRONIC ENCYCI.OPEDIA OF CHI. (2005), http://www.encyclopedia.chicagohistory.org/ pages/27.html, archived at https://perma.cc/WPM8-5VX5.

${ }^{41}$ Gary Massoni, Perspectives on Operation Breadbasket, in Chicago 1966: Open Housing Marches, Summit Negotiations, and Operation Breadbasket 192 (David J. Garrow ed., 1989).

${ }^{42}$ Peeks, supra note 38, at 270-72; see also Cheryl Lynn Greenberg, Or Does It Explode: Black Harlem in the Great Depression (1991).

${ }^{43}$ See generally Delores Nason McBroome, Paraldefl. Communities: African AmeriCANS in CALIFornia's EAST BAy 1850-1963 (1993).

${ }^{44}$ August Meier \& Elliot Ruidwick, The Origins of Nonviolent Direct Action in AfroAmerican Protest, in Along the COlor Line: EXPLORATIONS IN THE Black EXPERIENCE 316 (1976).

${ }^{45}$ W.E.B. DuBoise, Editorial, Boycotts, The Crisis: a ReCord of The Darker RACes, September 1934, at 268-69.

${ }^{46}$ See PEeks, supra note 38, at 272; MeIER \& Rudwick, supra note 44, at 328-29. 
major bus lines to hire Black drivers and mechanics; and persuaded the three subway lines (one public, two private) to employ Blacks as change makers, guards, and conductors. ${ }^{47}$

Despite these successes, always hanging over the demonstrators was the threat of an injunction. Injunctions were used regularly in the preRoosevelt era to stymie the work of labor unions, but their use was curtailed on the eve of the New Deal by passage of the Norris-LaGuardia Anti-Injunction Act of 1932, which limited the jurisdiction of the federal courts to grant an injunction "in a case involving or growing out of a labor dispute." ${ }^{48}$ But were the "Don't Shop Where You Can't Work" boycotts labor disputes? In 1934, two decisions, from state courts in Maryland and New York, ruled they were not. ${ }^{49}$ In the New York case, which received more publicity and became more influential, a Harlem group had demanded that a local shoe store - A.S. Beck and Company - hire 50\% Black employees. ${ }^{50}$ The store sought an injunction. The demonstrators insisted that no injunction could be issued because their dispute with Beck was a labor dispute." The court disagreed, holding that this was a "racial dispute" not a "labor dispute," and issued the order prohibiting picketing. ${ }^{52}$ Although the court did not directly confront the legitimacy of a demand for proportional hiring, compared with a demand of non-discrimination, that question simmered in the background. Just as our courts today respond differently to racial quotas than to promotion of racial diversity, ${ }^{53}$ civil rights advocates throughout the twentieth century were also divided. Moderate groups like the NAACP were cautious about demands for proportional representation, while more activist groups favored them. ${ }^{54}$

The New York and Maryland cases discouraged activists and empowered employers, but the question did not die. The issue arose again in Washington D.C. when the New Negro Alliance, a civil rights group whose leaders included the great legal strategist William H. Hastie, dean of the

${ }^{47}$ See PeEks, supra note 38 , at 272-73.

${ }^{48}$ Norris-LaGuardia Anti-Injunction Act of $1932 \S 1,29$ U.S.C. $\$ 101$ (2012).

49 See A.S. Beck Shoe Corp. v. Johnson, 274 N.Y.S. 946 (1934); Green v. Samuelson, 178 A. 109 (Md. 1935); see also Paul D. Moreno, From Direct Action to Affirmative AcTION 33-41 (1997); Earl M. Curry, Jr., Employment Equality in a Color-Blind Society, 5 AKRON L. Rev. 165 (1972).

${ }^{50}$ See A.S. Beck Shoe Corp., 274 N.Y.S. at 948.

${ }^{51}$ See id. at 952.

${ }^{52}$ See id. at 953; see also GreEnBerg, supra note 42, at 124.

${ }^{53}$ See Regents of Univ. of California v. Bakke, 438 U.S. 265, 269 (1978) (in university admissions, racial quotas are impermissible, but race-conscious decision-making in support of diversity policies is permitted); Grutter v. Bollinger, 539 U.S. 306 (2003) (University of Michigan Law School's use of race as part of a diversity admissions program was permissible); Gratz v. Bollinger, 539 U.S. 306 (2003) (University of Michigan undergraduate assignment of points toward admission based on race was an illegal quota system).

${ }^{54}$ See Paul D. Moreno, From Direct Action to Afrirmative Action $95-97$ (1997) (split between local and national NAACP over Hughes' demand for proportional representation); see also Robert J. Weiss, "We Want Jobs": A History of Affirmative Action 18 (1997). 
Howard University Law School. ${ }^{55}$ The Alliance began picketing at one of the Sanitary Grocery Stores (a wholly owned subsidiary of Safeway Stores) located in a Black neighborhood, demanding that they hire Black workers. Critically, as it turned out, the Alliance did not demand that the store hire proportionately, only that they stop discriminating against Black job applicants. Their signs read, "Do Your Part! Buy Where You Work! No Negroes Employed Here!"56

The store sought an injunction, which was issued over the defense that this was a labor dispute. The Alliance appealed to U.S. Court of Appeals, which upheld the court's order. ${ }^{57}$ The Alliance then appealed to the U.S. Supreme Court, represented by a team that included the young lawyer Thurgood Marshall, ${ }^{58}$ who had only recently graduated from Howard Law and joined the legal staff of the NAACP (Marshall would go on, as chief counsel of the NAACP Legal Defense Fund, to lead the litigation strategy that led to the decision in Brown v. Board of Education, and to then serve as Solicitor General of the United States and as the first Black Justice of the United States Supreme Court).

By a vote of 6-2, in an opinion by Justice Owen Roberts, the Supreme Court held that the dispute between the Alliance and the grocery store company was a labor dispute within the meaning of the Norris-LaGuardia AntiInjunction Act. The majority opinion noted that the picketers were not committing, or asking the store to commit, any illegal act, and that " $[\mathrm{r}]$ ace discrimination by an employer may reasonably be deemed more unfair and less excusable than discrimination against workers on the ground of union affiliation." $" 59$

In the wake of the Sanitary Grocery Stores case there were many more "Don't Shop Where You Can't Work" campaigns across the country, increasingly in smaller cities and in the South. Documented examples include Newark (1938), Dayton (1938), Youngstown (1939), Evansville (1939), Houston (1939), Memphis (1939), Kansas City (1939), Oakland (1939), Berkeley (1939), Jackson (TN) (1940), Rock Hill (SC) (1940), Lockland $(\mathrm{OH})(1941)$, Newport News (1941), and Alliance (OH) (1941). ${ }^{60}$ But with the U.S. entry into World War II the boycotts paused. They would begin again soon after the war ended, most importantly in Richmond, California and Philadelphia, Pennsylvania.

Richmond is a mid-sized city on the San Francisco Bay, nearly adjacent to Berkeley and a few miles from Oakland. Richmond and its Black population had grown exponentially during the war, as Black migrants from the South came to work in the Kaiser Shipyards, building hundreds of "Victory

${ }^{55}$ See PEeks, supra note 38 , at 276.

${ }_{56}^{56}$ See New Negro Alliance v. Sanitary Grocery Co., 303 U.S. 552, 557 (1938).

${ }^{57}$ Id. at 559.

${ }^{58}$ PEEKS, supra note 38, at 277.

${ }^{59}$ New Negro Alliance, 303 U.S. at 561. The suggestion by the Court of a competition between civil rights for Black Americans and labor rights for American workers would roil both the civil rights movement and the labor movement ever after.

${ }^{60}$ Meier \& Rudwick, supra note 37 , at 316 , tbl. II. 
Ships" for the U.S. Navy and merchant marine. In 1930 only 48 of Richmond's 20,093 residents were Black. By 1940 it was 3,468 of 23,642 and by 1950 it was 13,374 of 99,545. ${ }^{61}$ Overall, an estimated 50,000 Black Americans migrated from the South to the East Bay region (primarily Richmond, Oakland, and Berkeley) between 1942 and 1945.62

When the Lucky Stores chain of markets decided to open a market in 1947 in a largely Black Richmond neighborhood, but with no Black employees, a local civil rights group, the Progressive Citizens of America, joined by the NAACP, decided to picket the store, asking Black customers to boycott the store until the store agreed to hire Black employees in proportion to their Black clientele. ${ }^{63}$ The store sought an injunction against the picketing, relying on the A.S. Beck decision from New York, and distinguishing the Sanitary Grocery Company case with the following argument: In the Sanitary Grocery case the Supreme Court held that picketing in support of non-discrimination was protected by the Anti-Injunction Act because the objective sought was lawful. But here, the picketers are seeking proportional hiring, or racial quotas. Proportional hiring is discriminatory, and thus in violation of public policy. Thus, the objective sought is not lawful, and picketing to demand an unlawful objective is not protected by the statute, nor by the First Amendment to the U.S. Constitution.

A reader might pause here to express wonder at the argument that racial discrimination in 1947 was a violation of public policy, and thus unlawful. During the war years, President Roosevelt had used his war powers to create a federal Fair Employment Practices Commission (FEPC) and authorized it to advocate on behalf of non-discriminatory hiring in war industries, including Richmond's shipyards. But when the war ended, the Congress, facing Southern resistance, had de-funded the FEPC, and it was disbanded. California would pass an anti-discrimination act, prohibiting racial discrimination in employment, but not until 1959. No one was arguing with any force that Lucky's decision not to hire Black clerks was a violation of law, yet Lucky argued that a demand that they affirmatively hire Black employees was unlawful. ${ }^{64}$ And it worked.

${ }^{61}$ U.S. Bureau of the Census, Stxteenth Census of the United States Taken in the Year 1940, at 601 (1943); U.S. Bureau of the Census, Seventeenth Census of the United States Taken in The Year 1950, at 5-102 (1951). By 2000 Richmond's population of 99,216 was majority-minority, including Blacks $(35,777)$, Hispanic/Latinos $(26,319)$, Asians $(12,198)$, or mixed race and/or otherwise non-whites $(18,987)$; the White population had dropped from 85,329 in 1950 to 31,117. See Richmond California Population and Demographic Resources, AREACONNECT, http://richmondca.areaconnect.com/statistics.htm, archived at https://perma.cc/2M9D-XLC5 (last visited Dec. 18, 2017).

${ }^{62}$ Lawrence Bunch, Martha Kendall Crouchett and Lonnie Winnacker, Visions Toward Tomorrow: The History of the East Bay Afro-American Community 1852-1977, at 45-46 (1989), cited in Frederic White, Justice Carter's Dissent in Hughes v, Superior Court of Contra Costa County, in The Grent Dissents of the "Lone Dissenter": Justice Jesse W. Carter's Twenty Tumultuous Years on the Califfornia Supreme Court 59 (David B. Oppenheimer and Allan Brotsky eds., 2010).

${ }^{63}$ See Hughes v. Superior Court, 339 U.S. 460, 461 (1950).

${ }^{64} \mathrm{I}$ have argued that the Hughes decision established a California common law prohibition on employment discrimination independent of the California statutory scheme. See David 
The Superior Court (the trial court in the California State court system) issued an injunction prohibiting picketing at the store on May 26, 1947. On June 21, Richmond NAACP leaders ${ }^{65}$ John Hughes and Louis Richardson, returned to the store to picket, holding signs stating "Lucky Won't Hire Negro Clerks in Proportion to Negro Trade - Don't Patronize." 66 They were arrested, tried for criminal contempt, convicted and sentenced to $\$ 20$ fines plus two days in jail. ${ }^{67}$ On appeal, the convictions were initially reversed. The California Court of Appeal decision explained:

"All that we are here holding is that it is in accord with sound public policy to permit Negroes, a discriminated against and subjugated group in our society, to picket to attempt to secure equality in employment practices from those employers who cater to Negro patronage. The right is granted not because the picketers are members of a minority group, but because that minority group is economically discriminated against, and is attempting to rectify that condition. $" 68$

But on further appeal to the California Supreme Court, and then the U.S. Supreme Court, the convictions were reinstated. ${ }^{69}$ As Justice Frankfurter explained in his unanimous opinion for the U.S. Supreme Court, referencing and affirming the California Supreme Court:

"That court [the California Supreme Court] held that the conceded purpose of the picketing in this case - to compel the hiring of Negroes in proportion to Negro customers - was unlawful even though pursued in a peaceful manner. Having violated a valid injunction, petitioners were properly punishable for contempt. 'The controlling points,' according to the decision of the Supreme Court of California, 'are that the injunction is limited to prohibiting picketing for a specific unlawful purpose, and that the evidence justified the trial court in finding that such narrow prohibition was deliberately violated.' 32 Cal.2d 850, 856, 198 P.2d 885,888 .

What was the difference between the picketing of the Sanitary Grocery store in Washington D.C. and the Lucky Store in Richmond, California? In

B. Oppenheimer and Margaret M. Baumgartner, Employment Discrimination and Wrongful Discharge: Does the California Fair Employment and Housing Act Displace Common Law Remedies, 23 U. S.F. L. Rev. 145 (1989); see also, Rojo v. Kliger, 801 P. 2d 373, 379 n.6 (Cal. 1990) (citing article with approval).

${ }^{65}$ Shirley Ann Wilson Moore, To Place Our Deeds: The African American ComMUNity in Richmond, CAlifornia, 1910-1963 90 (2000).

${ }^{66}$ Hughes, 339 U.S. at 462.

${ }^{67} \mathrm{Id}$.

${ }^{68}$ Hughes v. Superior Court for Contra Costa County, 186 P. 2d. 756, 766 (Cal. Ct. App. 1947), vacated, 198 P.2d 885 (Cal. 1948), aff'd 339 U.S. 460 (1950). The opinion was by Justice Peters, who would soon thereafter join the California Supreme Court as an Associate Justice.

${ }^{69}$ Hughes, 339 U.S. at 462, aff'g 198 P.2d 885 (Cal. 1948). 
the former case the pickets were understood to be demanding an end to discrimination, but not proportional hiring; in the latter case, they were demanding racial quotas. This difference in approach reflected a tension within the Civil Rights Movement between demanding proportional representation or demanding race neutral hiring. As the Sanitary Grocery and Lucky Stores cases make clear, the Supreme Court was willing to affirm the legitimacy of protesting discrimination, but unwilling to give any approval to demands for proportional hiring. Demands for proportional hiring nonetheless persisted, and would become a critical part of Dr. King's campaign for racial justice in the last six years of his life.

\section{Rev. Leon Sullivan \& the Selective Patronage Movement}

Despite the Supreme Court's unanimity in the Hughes case, demands for hiring quotas continued, and continued to be controversial. ${ }^{70}$ Rev. Leon Sullivan's Selective Patronage movement in Philadelphia, itself inspired by the "Don't Shop Where You Can't Work" campaigns of the 1920s-30s, ${ }^{71}$ was a provocative continuation of those efforts.

Rev. Sullivan was born in 1922 in Charleston, West Virginia. ${ }^{72}$ He became the pastor of the Zion Baptist Church of Philadelphia in 1950, the year the Hughes opinion was issued by the Supreme Court, after having ministered two churches in New York and New Jersey. ${ }^{73}$ Deeply committed to "economic justice issues for African American workers, the expansion of black business enterprises, and the internationalization of the social justice and economic empowerment," Rev. Sullivan was an activist within his community. ${ }^{74}$ His Selective Patronage movement arose out of his observation that "when it came to jobs at banks, insurance companies, corporations, and retail stores, black people had virtually no chance. The doors were closed."75 Through the Selective Patronage movement, he was attempting, as he put it, to "get the doors opened or knock them down."76 It was also an opportunity to bring the Civil Rights Movement and demands for Black employment north. "Some of us were picketing the five-and-ten to support the lunch counter sit-ins in the South," Sullivan explained, "when we realized that the North and East had problems that were just as acute."

${ }^{70}$ See generally Earl M. Curry, Jr., Employment Equality in a Color-Blind Society, 5 AKRON L. Rev., no. 2, 1972, at 165 (collecting cases in the $1950 \mathrm{~s}$ and 1960s).

${ }^{71}$ See infra text accompanying notes 106-132.

${ }^{72}$ Leon Sullivan, Resume, http://www.thekingcenter.org/archive/document/rev-leon-howard-sullivans-resume\#, archived at https://perma.cc/XB98-MXV6 (last visited Dec. 18, 2017).

${ }^{73} I d$.

${ }^{74}$ V. P. Franklin, "The Lion of Zion": Leon H. Sullivan and the Pursuit of Social and Economic Justice: Introduction, 96 J. AFR. AM. Hist. 1, 40 (2011).

${ }^{75}$ Leon Sullivan, Moving Mountains: The Principlees and Purposes of Leon SulliVAN $11(1998)$.

${ }_{76}$ Id.

${ }^{77}$ Stacy Kinlick Sewell, The "Not-Buying Power" of the Black Community: Urban Boycotts and Equal Employment Opportunity, 1960-1964, 86 J. Afr. AM. Hist. 135, 139 (2004). 
In 1958, Rev. Sullivan devised a civil rights strategy that looked back to the "Don't Shop Where You Can't Work" campaigns and leveraged the formidable power of the Black preacher. ${ }^{78}$ In partnership with 400 other Black ministers, he founded the "Philadelphia Selective Patronage Movement" to secure jobs at local businesses for Black community members through threat of boycott. ${ }^{79}$ Under his leadership, committees of ministers would determine which companies to target based on employment data revealing disproportionately low numbers of African Americans employed by the company. Then, they would meet with the top executive of the company, make their demands, and designate a compliance period, usually between four to six weeks. If the company refused to hire Black workers in the numbers demanded, the committee ministers would call a Saturday midnight meeting during which the 400 ministers would vote on whether or not to boycott the company. If the vote to boycott passed, the ministers would use the "power of the pulpit" to convey to their congregation that the particular company would be boycotted the following Sunday morning. "By Monday morning," Rev. Sullivan later noted, "three hundred thousand black people around the city had heard the message." ${ }^{0}$ With this message, African American patrons would refuse to purchase goods and services at the targeted company. Once the company complied with the demands, the boycott was called off.

Once the minimum number of jobs was secured, the 400 ministers would continue to monitor the company to ensure that they continued to employ fair employment practices. They demanded that companies open positions to Black workers in supervisory, clerical, and skilled posts from which they had previously been excluded. Rev. Sullivan was adamant about the goals underlying the Selective Patronage movement's demands. He commented, "Yes, we are asking for discrimination against white people in upgrading a black man over a white man into a job classification where blacks have been excluded or where employed in insufficiently large numbers. In time that white man will be promoted into the higher job classification anyhow. Black men have been waiting for a hundred years; white men can wait for a few months!"81

${ }^{78}$ Leon Sullivan, Build, Brother, Bulld 70 (1969).

${ }^{79}$ Sullivan, supra note 75 , at 12 . Note that though Rev. Leon Sullivan now is recognized as the leader behind the Selective Patronage movement, at the time his role was much less certain. As one scholar notes, "Sullivan did not emerge immediately as the force behind the 'Selective Patronage Campaign.' In fact, Philadelphia's newspapers were hard-pressed to name the ringleaders - and that was exactly what the ' 400 Ministers' wanted. Sullivan himself admitted only to being a 'servant of the leaders.' Two years after the first campaigns, the Philadelphia Tribune would note that its leadership, "has never been admitted, the top man could be the Reverend Leon Sullivan." Kinlick Sewell, supra note 77, at 140. Sullivan subsequently acknowledged his role in his autobiography and other works. See e.g., Leon Sullivan, supra note 72 , at 14,25 .

${ }^{80}$ Sullivan, supra note 75 , at 13.

${ }^{81}$ Id. at 79. 
According to Rev. Sullivan, between 1958 and 1962 the 400 ministers secured approximately 2,000 skilled jobs for Black workers, ${ }^{82}$ boycotted 29 companies, and affected the hiring practices of many more businesses that agreed to the movement's demands in order to avoid a boycott. ${ }^{83}$ By 1962 , an estimated 300 businesses had agreed to hire Black employees. ${ }^{84}$

\section{Dr. King's TRIP to India: "I am an Untouchable"}

As an admirer of Mahatma Gandhi, Dr. King sought to emulate his philosophy of nonviolence in his 1956 boycott campaign against bus segregation in Montgomery. ${ }^{85}$ As King wrote in 1959, "While the Montgomery boycott was going on, India's Gandhi was the guiding light of our technique of non-violent social change." 86 The resounding success of the campaign led Dr. King to believe all the more in the applicability of Gandhian philosophy in the Black struggle for equal rights. ${ }^{87}$

King was thus thrilled when Jawaharlal Nehru, the Prime Minister of India, expressed his interest in meeting Dr. King during a visit to New York in $1956 .{ }^{88}$ The meeting was postponed, but Dr. King received a letter from Nehru inviting him to India ${ }^{89}$ and three years later he was able to accept. ${ }^{90}$ He travelled to India for a five-week tour along with his wife, Coretta Scott King, and historian Lawrence Reddick, who had just published a book about Dr. King's embrace of nonviolence, "Crusader Without Violence: A Biography of Martin Luther King Jr.".

In preparing for the trip, Dr. King began to delve into the problems of the Hindu caste system, which had defined rights and obligations among Hindus for at least a millennium..$^{91}$ The Laws of Manu, an ancient legal text with a profound impact on Hindu culture, codified this system of stratification by dividing society into four varnas or castes $^{92}$, each with different du-

${ }^{82} I d$. at 76.

${ }^{83} \mathrm{Id}$. at 13.

${ }^{84} I d$.

${ }^{85}$ Dr. Martin Luther King, Jr., My Trip to the Land of Gandhi, Ebony Magazine, Jul. 1959 [hereinafter King, Ebony].

${ }^{86}$ Id.

${ }^{87} I d$.

${ }^{88}$ See Martin Luther King, Jr., From Jawaharlal Nehru, in V: ThreShOLd OF A NEW Decade January 1959-December 1960, The Papers of Martin Luther King, Jr. 107-08 (Clayborne Carson et al. eds., 2000).

${ }^{89} \mathrm{Id}$. at $107-08$.

${ }^{9}$ See King, Ebony, supra note 85.

${ }^{91}$ Alberuni (c. A.D. 1020) noted that certain endogamous occupational groups lived outside villages and had limited interaction with others. See Marc Galanter, Competing EQuAltTIES 13 n.25 (1984).

${ }_{92}$ The Laws of Manu, also known in Sanskrit as Manava-dharma-shastra, is attributed to Manu, the first man according to Indian lore. Of uncertain date, various sources place it between $200 \mathrm{BC}$ to $200 \mathrm{AD}$. These laws provided a social structure by codifying the duties and obligations of the different castes, the relationship between men and women, the rights of rulers, death, marriage, ritual practices, and all other aspects of human life. 
ties, obligations and social standing. For the Sudra, or untouchable, ${ }^{93}$ this meant being relegated to working as cleaners, cobblers, and rag pickers, tasks that were considered dirty and low paying by other castes.

By the end of the nineteenth century, social reformers began to see caste hierarchy as a serious issue demanding attention. The issue was given particular importance when discrimination against Indians in South Africa came to light in the $1880 \mathrm{~s}$, drawing parallels to discrimination by Indians against their own. ${ }^{94}$ For Gandhi, who arrived in South Africa in 1893 as a young lawyer, his advocacy on behalf of Indians in South Africa helped develop his empathy for low caste Indians when he returned home in 1914.

By the time of independence in 1947, the caste system was widely frowned upon as divisive, detrimental to nationalism, and an impediment to India's growth as a democracy. ${ }^{95}$ Soon after, an official policy of "reservations" took shape. A key part of the reforms on the untouchability issue is the Indian Constitution itself. It includes safeguards for the untouchables in the Fundamental Rights section by banning discrimination on grounds of caste by the government and private individuals. It promotes the advancement of the untouchables by providing for "reservations," a policy of reserving spaces through proportional representation quotas in public employment and education. ${ }^{96}$ Some key sections encapsulating this policy of affirmative action-type quotas in favor of the untouchables include Article 16(4), which permits the State to reserve appointments in favor of the backward classes, Article 15, which bans discrimination by the Government, and Article 29(2), which bans discrimination in governmental education systems. ${ }^{97}$

Reservations policy extends to three different kinds of groups..$^{98}$ The first are the "Scheduled Castes," previously treated as "untouchables." The second are the "Scheduled Tribes," formed by the various tribes scattered in remote locations in India. Finally, third are the "Other Backward Classes," who, while low in the caste hierarchy, are not as low as the Scheduled Castes. ${ }^{99}$ Broadly speaking, there are three different kinds of reservations. The first are reservations for jobs in the public sector, educational institu-

${ }^{93}$ As the term untouchable is considered offensive, it has been replaced with different nomenclature. The official term is "Scheduled Castes"; Gandhians refer to them as "Harijans" (children of God), but this has been viewed by some as condescending, and some use the term "Dalits" (the oppressed). "Backward Classes" includes a much broader group. See GALANTER, supra note 91 , at 13.

${ }^{94}$ Id. at 24

${ }_{95} \mathrm{Id}$. at 37 . I do not mean to suggest that this recognition, or the remedies described herein, have fully solved the problem. For a report on caste discrimination in India today, see Human Rights Watch, Clefaning Human Waste: "Manual. Scavenging," Caste, and DisCRIMINATION IN INDIA (2014), https://www.hrw.org/report/2014/08/25/cleaning-humanwaste/manual-scavenging-caste-and-discrimination-india, archived at https://perma.cc/Q7PG$5 E K N$.

${ }^{96}$ GALANTER, supra note 91 , at 38 .

${ }^{97}$ Id. at 42

${ }^{98} \mathrm{Id}$.

${ }^{99} \mathrm{Id}$. 
tions and the legislature, including quotas to ensure proportional representation of the Scheduled Castes and Scheduled Tribes in the lower house of the Indian parliament (Lok Sabha). ${ }^{100}$ The second are programs for spending on the provision of services such as loans, scholarships, etc. on the three groups. The third are legal tools to prevent their exploitation and discrimination. ${ }^{101}$

In his account of the tour published in Ebony magazine, Dr. King describes the reception of the Indian public as "grand." He wrote: "Virtually every door was open to us. We had hundreds of invitations that the limited amount of time did not allow us to accept. We were looked upon as brothers with the color of our skins as something of an asset. But the strongest fraternity was the common cause of minority and colonial peoples in America, Africa, and Asia struggling to throw off racialism and imperialism."102

Amidst this warm welcome, Dr. King met Prime Minster Nehru on February 10, 1956, and in a four-hour long discussion, the two leaders exchanged ideas on the problem of caste discrimination in India and its relation to race discrimination in the United States. As Dr. King relates in his 1964 book, Why We Can't Wait, ${ }^{103}$ Prime Minster Nehru asserted that ameliorating mass poverty required national industrial policy and affirmative action for the untouchables. A few years later, Dr. King wrote of the connection between Indian reservations and American affirmative action:

Among the many vital jobs to be done, the nation must not only radically readjust its attitude toward the Negro in the compelling present, but must incorporate in its planning some compensatory consideration for the handicaps he has inherited from the past. It is impossible to create a formula for the future which does not take into account that our society has been doing something special against the Negro for hundreds of years. How then can he be absorbed into American life if we do not do something special for him now, in order to balance the equation and equip him to compete on a just and equal basis?

Whenever this issue of compensatory or preferential treatment for the Negro is raised, some of our friends recoil in horror. The Negro should be granted equality, they agree; but he should ask for nothing more. On the surface, this appears reasonable, but it is not realistic. For it is obvious that if a man is entered at the starting line in a race three hundred years after another man, the first would have to perform some impossible feat in order to catch up with his fellow runner.

${ }^{100}$ See Constrtution of IndiA, pt. XVI, art. 330 (India).

${ }^{101}$ Galanter, supra note 91 , at 43.

${ }^{102}$ King, Ebony, supra note 85.

103 Dr. Martin Luther King, JR., Why We Can't Wait, 134-35 (1964). The book was published in July of 1964 , the month that President Johnson signed into law the 1964 Civil Rights Act. 
Several years ago, Prime Minister Nehru was telling me how his nation is handling the difficult problem of the untouchables, a problem not unrelated to the American Negro dilemma ... . The Indian government spends millions of rupees annually developing housing and job opportunities in villages heavily inhabited by untouchables. Moreover, the Prime Minister said, if two applicants compete for entrance into a college or university, one of the applicants being an untouchable and the other of a high caste, the school is required to accept the untouchable.

Professor Lawrence Reddick, who was with me during the interview, asked: 'But isn't that discrimination?' 'Well it may be,' the Prime Minister answered. 'But this is our way of atoning for the centuries of injustices we have inflicted upon these people. ${ }^{104}$

Dr. King often invoked his conversation with Prime Minister Nehru in calling for affirmative action-type remedies to American racism. And his strong sense of identification with low caste Indians could not have been stronger. As he told his congregants at Ebenezer Baptist Church in Atlanta, in a sermon delivered on July 4, 1965, the day before the 1964 Civil Rights act took effect:

I remember when Mrs. King and I were in India, we journeyed down one afternoon to the southernmost part of India, the state of Kerala, the city of Trivandrum. That afternoon I was to speak in one of the schools, what we would call high schools in our country, and it was a school attended by and large by students who were the children of former untouchables. ... The principal introduced me and then as he came to the conclusion of his introduction, he says, "Young people, I would like to present to you a fellow untouchable from the United States of America." And for the moment I was a bit shocked and peeved that I would be referred to as an untouchable. (Glory to God)

Pretty soon my mind dashed back across the mighty Atlantic. And I started thinking about the fact that at that time no matter how much I needed to rest my tired body after a long night of travel, I couldn't stop in the average motel of the highways and the hotels of the cities of the South. I started thinking about the fact that no matter how long an old Negro woman had been shopping down-

${ }^{104} \mathrm{Id}$. King repeatedly told this story about his conversation with Prime Minister Nehru, including in his testimony before the Kerner Commission (The National Advisory Commission on Civil Disorders), where he called for a massive investment in jobs and housing for Black Americans to stem the growing tide of riots spreading across the country. See Martin Luther King, Jr., President, S. Christian Leadership Conference, Statement to the National Advisory Commission on Civil Disorders in Atlanta, Georgia (Oct. 23, 1967), http://www.thekingcenter .org/archive/document/mlk-statement-national-advisory-commission-civil-disorders, archived at https://perma.cc/TQW9-37E3. 
town and got a little tired and needed to get a hamburger or a cup of coffee at a lunch counter, she couldn't get it there. (Preach) I started thinking about the fact that still in too many instances, Negroes have to go to the back of the bus and have to stand up over empty seats. (Yes, sir) I started thinking about the fact that my children and the other children that would be born would have to go to segregated schools. I started thinking about the fact: twenty million of my brothers and sisters were still smothering in an airtight cage of poverty in an affluent society. I started thinking about the fact: (Make it plain) these twenty million brothers and sisters were still by and large housed in rat-infested, unendurable slums in the big cities of our nation, still attended inadequate schools faced with improper recreational facilities. And I said to myself, "Yes, I am an untouchable, and every Negro in the United States of America is an untouchable." And this is the evilness of segregation: it stigmatizes the segregated as an untouchable in a caste system. We hold these truths to be self-evident, if we are to be a great nation, that all men (all men) are created equal. God's black children are as significant as his white children. (Yes, sir) "We hold these truths to be self-evident." One day we will learn this. ${ }^{105}$

\section{Operation Breadbasket}

Dr. King was no stranger to boycotts: he had been thrust into the leadership of the Civil Rights Movement in 1956 with the Montgomery bus boycott, and his most important de-segregation campaign - the Birmingham Campaign of 1963 - was organized around a boycott of Birmingham's segregated businesses. But with Operation Breadbasket, which brought together demands for proportional representation in the employment of Black workers with the boycott technique, King reached back to the "Don't Shop Where You Can't Work" movement that began in the 1920s and the Selective Patronage movement spearheaded by Rev. Sullivan, and looked forward toward the 1964 Civil Rights Act, which would prohibit racial discrimination in employment, while permitting, but not requiring, preferential hiring and promotion of Black workers. ${ }^{106}$

Inspired by the "Don't Shop Where You Can't Work" campaigns of the 1920s-40s, the Selective Patronage movement orchestrated by Rev. Leon

${ }^{105}$ Martin Luther King, Jr., Reverend, Ebenezer Baptist Church, Sermon on "The American Dream" at Ebenezer Baptist Church (Jul. 4, 1965), http://kingencyclopedia.stanford.edu/ encyclopedia/documentsentry/doc_the_american_dream/, archived at https://perma.cc/876XW5K9.

${ }^{106}$ See Steelworkers v. Weber, 443 U.S. 193, 195 (1979) (1964 Civil Rights Act permits, but does not require, race-conscious affirmative action hiring and promotion plans, subject to certain limitations). See also, David B. Oppenheimer, The Disappearance of Voluntary Affirmative Action from the U.S. Workplace, 24 J. OF PoverTy \& Soc. Just. 37 (2016). 
Sullivan in Philadelphia between 1958 and 1962, and what he observed on his 1959 trip to India, Dr. King led a nationwide campaign demanding the proportional hiring of Black workers by local business, backed up by boycott threats. ${ }^{107}$ "Operation Breadbasket" launched in Atlanta in 1962, and between that time and his murder in 1968, Dr. King worked relentlessly to bring this proportional hiring/boycott program to cities across America. ${ }^{108}$

Operation Breadbasket began when Dr. King invited Rev. Sullivan to Atlanta to "help him develop a similar program for America." 109 With the support of the Southern Christian Leadership Conference (SCLC), Operation Breadbasket began in Atlanta in 1962. Operation Breadbasket organizers demanded basic employment data from companies that revealed "the total number of workers in each job category compared with the number of Black workers in these same jobs." 110 Employers with a low proportion of Black workers would be asked to correct the imbalance, or face a boycott. As the Operation Breadbasket guidelines explained, "Basically the demands are for a percentage of the jobs comparable to numbers of Black people in the city and the volume of business done in the Black ghetto. . For instance, if the Black population is $20 \%$ of the population of the city, then $20 \%$ Black employment would be a fair representation in the company. This might need to be modified, however. . .For example, if the company does $30 \%$ of its business in the Black community, and even though the population is only $20 \%$ Black, a guideline of $30 \%$ might be a more appropriate basis for demands."

In expressing the rationale behind the program, Dr. King stated:

${ }^{107}$ Massoni, supra note 41, at 193.

108 See generally, Operation Breadbasket (1962-1972), THE KING INST. ENCYCL_OPEDIA, http://kingencyclopedia.stanford.edu/encyclopedia/encyclopedia/enc_operation_breadbasket/, archived at hitps://perma.cc/4XNM-4JWV. See also, Martin Luther King, Jr., President, S. Christian Leadership Conference, Annual Report at the Eighth Annual Southern Christian Leadership Conference Convention (Sep. 28, 1964), http://www.thekingcenter.org/archive/ document/mlk-annual-report-1964-sclc-convention, archived at https://perma.cc/49KC6RWH; Interview by Associated Press with Martin Luther King, Jr., President, S. Christian Leadership Conference, on Operation Breadbasket (Jul. 28, 1967), http://www.thekingcenter .org/archive/document/mlk-interview-associated-press-operation-breadbasket, archived at https://perma.cc/N3DN-AGXJ; Press Release, Rev. David Wallace \& Rev. Jesse Jackson, Operation Breadbasket (Aug. 25, 1966), http://www.thekingcenter.org/archive/document/operation-breadbasket-0, archived at https://perma.cc/8BMS-T9M3; S. Christian LeAdership Conference, Operation BREAdBasket (1964), http://www.thekingcenter.org/archive/document/operation-breadbasket-pamphlet, archived at https://perma.cc/BF9X-EKZP.

${ }^{109}$ Sullivan, supra note 75 , at 14,25. After their first meeting, King wrote to Sullivan to express his thankfulness: "I cannot tell you what your stirring message did for all of us. I believe firmly that they will lead to one of the most inspiring movements that Atlanta has ever had. I will certainly keep you abreast with all of our developments and I am sure that your constant communication can be mutually beneficial." Letter from Martin Luther King, Jr., President, S. Christian Leadership Conference, to Leon H. Sullivan (Oct. 31, 1962), www thekingcenter.org/archive/document/letter-mlk-reverend-leon-h-sullivan, archived at https:// perma.cc/VAK6-TYLP.

${ }_{110}^{110}$ Massoni, supra note 41, at 197.

${ }^{\prime \prime} I d$. at 309-321 (August 1968 Guidelines for Operation Breadbasket Committees). For example, at the Chicago-based Borden Company, only 23 of the company's 435 employees were Black. Operation Breadbasket organizers demanded that the company hire another 64 
Operation Breadbasket firmly believes that any company doing business in the ghetto must radically reconstruct its employment practices commensurate with the profits which it is taking out of the community. For any company to receive sizeable profits from the Negro Community while employing only a small number of the community residents, and thus reinvesting only a small percentage of its profits back into the community is one of the factors which creates a slum. ${ }^{112}$

For Dr. King, the key word in Operation Breadbasket was "respect." He aimed to communicate to local businesses, "If you respect my dollars, you must respect my person." 113 Five years after Operation Breadbasket began in Atlanta, Dr. King estimated the program had secured 5,000 new jobs and "upgraded positions worth millions of dollars in annual income." 14

In 1966, as Operation Breadbasket gained traction in Atlanta, the program expanded to Chicago as part of a larger movement to bring Civil Rights campaigns to the North. In Chicago, the operation was led by Dr. King's long-time aide Rev. Jesse Jackson, who eventually took over the entire national effort after Dr. King's assassination in 1968. Operation Breadbasket was not a novel idea to Black Chicagoans. It's predecessor, the "Don't Shop Where You Can't Work" boycotts had their roots in Chicago. And beginning in 1963, the Chicago Black press reported on the developments of Operation Breadbasket in Atlanta and throughout the South. Headlines featuring the program's victories littered the pages of Chicago newspapers: "Atlanta Bakery Bows To Fair Hiring Request,"115 "Third Ga. Bakery Bows; Ends Biased Hiring Policy," 16 "Atlanta Ministers Spearheading Campaign For Jobs For Negroes," 117 "Fifth Bakery In Atlanta Agrees To Fair Hiring."18 These articles reported that within the first four months of Operation Breadbasket's boycotts in Atlanta, the project had succeeded in adding $\$ 400,000$ in annual income to the Black community. ${ }^{119}$

These headlines foreshadowed the Chicago experience of Operation Breadbasket as the program took full force. The Chicago Black press chron-

Black employees, to raise their total to 87 of 435 , or precisely $20 \%$, which was close to Chicago's overall Black population as of 1960 .

112 Press Release, Statement by Dr. Martin Luther King Jr. on Operation Breadbasket 2 (Dec. 12, 1967), http://www.thekingcenter.org/archive/document/operation-breadbasket-statement-dr-martin-luther-king-jr, archived at https://perma.cc/3HVB-FT8F.

${ }^{113}$ Annual Report from Dr. Martin Luther King, Jr. to the Southern Christian Leadership Conference 9 (Sept. 28, 1964), http://www.thekingcenter.org/archive/document/mlk-annual-report-1964-sclc-convention, archived at https://perma.cc/4KFU-3L2M.

${ }^{114}$ Interview by the Associated Press with Dr. Martin Luther King, Jr., President, Southern Christian Leadership Conference (July 28, 1967), http://www.thekingcenter.org/archive/ document/mlk-interview-associated-press-operation-breadbasket, archived at https://perma.cc/ M3K8-K9SC.

${ }^{115}$ Atlanta Bakery Bows to Fair Hiring Request, Chi. DaILy Def., Feb. 9, 1963.

${ }^{116}$ Third Ga. Bakery Bows; Ends Biased Hiring Policy, CHI. DAlLy DeF., Feb. 28, 1963.

${ }^{117}$ Atlanta Ministers Spearheading Campaign for Jobs for Negroes, ChI. DAlly DeF., Mar. 12, 1963.

${ }^{118}$ Fifth Bakery in Atlanta Agrees to Fair Hiring, Chi. Dally Def., Mar. 18, 1963.

${ }^{119} \mathrm{Id}$. 
icled Operation Breadbasket's development and success with headlines proclaiming, "Dairy Agrees to Double Number of Negro Workers,"120 "4th Dairy Oks More Jobs for Negros," 221 "5th Company Gives In to Breadbasket Demands for Jobs," 122 "Breadbasket, Food Chain Sign Contract,"123 "High Low Opens More Negro Jobs," 124 and "Campaign Here Nets Negros 224 New Jobs."125 Just one of these successes occurred in July of 1966 when the Dean Foods Company agreed to hire 45 Black employees within six different departments. ${ }^{126}$ In response to this victory, Rev. Jackson was quoted as stating: "The dirt, filth and shame of this city will be eradicated when men, like these Dean executives, take creative steps for the cause of justice, to bring about institutional changes in the businesses that have historically been negligent in their service responsibility to the total community." 127 Within the first 15 months of activism, Operation Breadbasket won "2,000 new jobs worth $\$ 15$ million a year in new income to the Black community." 128 This and subsequent successes led Dr. King to call Operation Breadbasket SCLC's "most spectacularly successful program" in Chicago. ${ }^{129}$

Operation Breadbasket was not the only boycott campaign calling for proportional hiring. The Congress of Racial Equality (CORE) also began a campaign in 1962, specifically demanding "compensatory hiring." 130 The organization won concessions from employers in Denver, Detroit, Seattle, Baltimore, and other cities in New York and California. ${ }^{131}$

From 1962-68, six of the twelve years between Dr. King's rise to leadership in the 1956 Montgomery bus boycott and his 1968 assassination, an important part of what he was doing was running a boycott campaign, to

${ }^{120}$ Basil Talbot, Jr., Dairy Agrees to Double Number of Negro Workers, CHI. Sun-Times, June 22, 1966, http://www.thekingcenter.org/archive/document/dairy-agrees-double-numbernegro-workers, archived at https://perma.cc/XM6B-KNDW.

${ }_{121}$ 4th Dairy Oks More Jobs for Negros, CHI. Sun-TrMes, July 7, 1966, http://www.thekingcenter.org/archive/document/dairy-agrees-double-number-negro-workers, archived at https://perma.cc/XM6B-KNDW.

${ }_{122} 5$ th Company Gives in to Breadbasket Demands for Jobs, ChI. Dally DeF., July 23, 1966, http://www.thekingcenter.org/archive/document/5th-company-gives-breadbasket-demands-jobs, archived at https://perma.cc/HY9E-7HHV.

${ }^{123}$ Breadbasket, Food Chain Sign Contract, CHI. Dally Der., Nov. 21, 1966, http://www .thekingcenter.org/archive/document/breadbasket-food-chain-sign-contract, archived at https:// perma.cc/F4V3-SYBS.

${ }^{124}$ High Low Opens More Negro Jobs, Chi. Dally News, Nov. 19, 1966, http://www .thekingcenter.org/archive/document/breadbasket-food-chain-sign-contract, archived at https:// perma.cc/F4V3-SYBS.

${ }_{125}$ Jerry Lipson, Campaign Here Nets Negros 224 New Jobs, Chi. Dail. News, Aug. 8 , 1966, http://www.thekingcenter.org/archive/document/chicago-daily-news-operation-breadbasket, archived at https://perma.cc/3Y92-RND2.

${ }^{126} 5$ th Company Gives In to Breadbasket Demands for Jobs, supra note 122.

${ }^{127} \mathrm{Id}$.

${ }^{128}$ Operation Breadbasket (1962-1972), MARTin LuTHER KinG, JR., EnCyClopedia, http:/ /kingencyclopedia.stanford.edu/encyclopedia/encyclopedia/enc_operation_breadbasket, archived at https://perma.cc/9WTP-5JAM (last visited Nov. 11, 2017).

${ }_{129}$ Id

130 Terry H. Anderson, The Pursuit of Fairness: A History of Affirmative Action 76 (2004).

${ }^{131}$ See id.; see also, WEISs, supra note 54 , at 60. 
demand racial quota hiring. To put those six years in perspective, they began around the time of the Albany, Georgia campaign, and continued through Birmingham, the 1963 March on Washington (site of the I Have a Dream speech), the Nobel Prize, the 1964 Civil Rights Act, Selma, the 1965 Voting Rights Act, the Cicero campaign, the Poor People's campaign, and Memphis. Many volumes have been written about each of these moments in Dr. King's life's work, but outside the reports of the SCLC and the Black press, almost nothing has been written about Breadbasket. Why? Perhaps the best answer was supplied by Dr. King in his book Why We Can't Wait, written in the wake of the Birmingham campaign: "Whenever this issue of compensatory or preferential treatment for the Negro is raised, some of our friends recoil in horror. The Negro should be granted equality, they agree; but he should ask for nothing more."132

\section{Dr. King's support of Class-Based Affirmative Action to Defeat Poverty and Racial Inequality}

While the primary focus of Dr. King's work was the problem of racial inequality, he saw poverty as both a problem linked to racism and a problem to be addressed regardless of race. Beginning in 1964, and repeatedly thereafter, King called for a "Bill of Rights for the Disadvantaged," later described as a "Social and Economic Bill of Rights." King announced his demand for a "Bill of Rights for the Disadvantaged" in his 1964 post-Birmingham book, Why We Can't Wait. ${ }^{133}$ As he described it at a May 28, 1964 "World March Toward Human Rights Luncheon" of the NAACP Legal Education and Defense Fund:134

the United States [must] launch a broad-based, comprehensive Bill of Rights for the Disadvantaged. . . . Such a measure must cover all disadvantaged. It is a simple matter of justice that while dealing creativity with the task of raising the Negro from backwardness, we should also rescue a large stratum of the disadvantaged whites. This nation has in its past adhered to the principle of special measures for the deprived. It was the principle behind land grants to farmers who fought in the Revolutionary army and the Veterans of G.I. Bill of Rights after World War II. It is the moral framework of social security, unemployment compensation and Child Labor Laws. It is indeed the essence of social justice and Christian morality. . .[Opportunity] can only be successfully achieved within the World March Towards Human Rights when

${ }^{132}$ Martin Luther King, JR., Why We Can't Wait, supra note 103, at 134.

${ }^{133} \mathrm{Id}$. at $137-138$.

${ }^{134}$ Remarks of the Rev. Dr. Martin Luther King, Jr. to the World March Toward Human Rights Luncheon (May 28, 1964) [hereinafter King, World March Remarks], http://www thekingcenter.org/archive/document/mlks-remarks-world-march-toward-human-rights-luncheon\#, archived at https://perma.cc/8RP2-QQGR. 
racial barriers to Negro opportunity and economic barriers to $\mathrm{Ne}$ gro and White alike have been eliminated from our socio-economic structure. . . there are millions of white persons who share our culture of poverty and lack of opportunity. . . To this day the poor in white skins also suffer deprivation and the humiliation of poverty, if not color. They are chained by the weight of discrimination though its badge of degradation does not mark them. It corrupts their lives, frustrates their opportunities, and withers their education. . .[I]n dealing creatively with the task of raising the Negro from backwardness we must also rescue a large stratum of the forgotten white poor. . What America needs is a Marshall plan to eradicate poverty. A rapid and steady economic growth is impossible without the productive power of the poor. . . A Bill of Rights for the Disadvantaged could well mark the rise of a new era, in which the full and vast wealth and energies of this nation would be used to attack the tenacious poverty which so paradoxically exists in the midst of plenty! $!^{135}$

Dr. King returned regularly to the need to lift all Americans out of poverty. ${ }^{136}$ In his 1967 testimony before the National Advisory Commission of Civil Disorders, also known as the Kerner Commission, Dr. King proposed:

[J]ust as we granted a GI Bill of Rights to war veterans, America [must] launch a broad based and gigantic bill of rights for the disadvantaged, our veterans of the long siege of denial. ... While Negroes form the vast majority of Americans disadvantaged, there are millions of white poor who would also benefit from such a bill. . . . It is a simple matter of justice that America in dealing creatively with the task of raising the Negro from backwardness should also be rescuing a large stratum of the forgotten white poor. A bill of rights for the disadvantaged would mark the rise of a new era in which the full resources of the society which so paradoxically exists in the midst of plenty. ${ }^{137}$

In the final year of his life, Dr. King began organizing a new March on Washington to address the problem of poverty for all poor Americans, named the Poor People's March. In planning the march, he reframed his earlier call for a "Bill of Rights for the Disadvantaged" to a "Social and

${ }^{135} \mathrm{Id}$. at 10.

${ }^{136}$ See, e.g., Martin Luther King, Jr., Remarks at the Eleventh Annual Southern Christian Leadership Conference: Where Do We Go from Here? (Aug. 16. 1967), https://kinginstitute.stanford.edu/king-papers/documents/where-do-we-go-here-delivered- 11 th-annual-sclcconvention, archived at https://perma.cc/RP8Z-F7LP.

${ }^{137}$ Martin Luther King, Jr., Statement to the National Advisory Commission on Civil Disorders, supra note 104 , at $8-9$. 
Economic Bill of Rights." 138 He wrote, "[w]e speak as black men and women on behalf of black men and women. But the rights which we insist upon do not apply only to our own people. They are, as this nation has proclaimed, but not practiced, the principle for two centuries, the rights of all men." 139 This last bill of rights demanded: (1) the right of every employable citizen to a decent job, (2) the right of every citizen to a decent income, (3) the right of a decent house and the free choice of neighborhood, ${ }^{140}(4)$ the right of an adequate education, (5) the right to participate in the decision making process, and (6) the right to the full benefits of modern science in health care. ${ }^{141}$

It should thus be clear that if we try to apply Dr. King's philosophy and activism to the contemporary question of whether affirmative action programs should provide preferences based on race or class, his answer would be "yes." He would not favor one to the exclusion of the other; he would support both.

\section{Why Affirmative Action? Dr. King's Legal Theory OF REPARATIONS}

What justification did Dr. King offer for his support for affirmative action-type programs? When we examine his written work, his speeches, and his testimony before the Kerner Commission, the consistent answer is the legal principle of reparations.

On August 28, 1963 Dr. King stood on the steps of the Lincoln Memorial and delivered his I Have a Dream speech. ${ }^{142}$ In it he memorably said, "I have a dream that my four little children will one day live in a nation where they will not be judged by the color of their skin but by the content of their character." 143 These words are now often used to justify the assertion that if Dr. King were alive today he would oppose race-conscious affirmative action. ${ }^{144}$ But when we read the entire speech, it turns out to be a plea for reparations, not a plea for color-blindness. Thus, Dr. King proclaimed:

In a sense we've come to our nation's capital to cash a check. When the architects of our Republic wrote the magnificent words of the Constitution and the Declaration of Independence, they

${ }^{138}$ Martin luther King, Jr., Demand for Social ani Economic Billl of Rights 2 (Feb. 6, 1968), http://www.thekingcenter.org/archive/document/economic-and-social-billrights\#, archived at https://perma.cc/PAM9-F2VC.

${ }^{139}$ Id.

140 Putting this in context, the Congress was then debating the 1968 Fair Housing Act, and would pass it into law two days after Dr. King's murder.

${ }^{141}$ See Martin Luther King, Jr., Demand for Social and Economic Bill. of Rights, supra note 138 , at $2-5$.

${ }^{142}$ Martin Luther King, Jr., Speech at the Historic March on Washington: I Have a Dream (Aug. 28, 1963), http://www.thekingcenter.org/archive/document/i-have-dream-1, archived at https://perma.cc/QR2P-9E2Z.

${ }^{143} I d$. at 3.

${ }^{144}$ See supra note 24. 
were signing a promissory note to which every American was to fall heir. This note was a promise that all men - yes, black men as well as white men - would be guaranteed the unalienable rights of life, liberty and the pursuit of happiness. It is obvious today that America has defaulted on this promissory note insofar as her citizens of color are concerned. Instead of honoring this sacred obligation, America has given the Negro people a bad check, a check which has come back marked "insufficient funds."

But we refuse to believe that the bank of justice is bankrupt. We refuse to believe that there are insufficient funds in the great vaults of opportunity of this nation. So we've come to cash this check, a check that will give us upon demand the riches of freedom and the security of justice. ${ }^{145}$

In his 1964 book, Why We Can't Wait, Dr. King again uses the principle of reparations to demand affirmative action-type programs. In the section of the book quoted earlier, in which he proposes a Bill of Rights for the Disadvantaged, with government programs in education, employment, health care and housing, here is his justification.

Few people consider the fact that in addition to being enslaved for two centuries, the Negro was during all those years robbed of the wages of his toil. No amount of gold could provide an adequate compensation for the exploitation and humiliation of the Negro in America down through the centuries. Not all the wealth of this affluent society could meet the bill. Yet, a price can be placed on unpaid wages. The ancient common law has always provided a remedy for the appropriation of the labor of one human being by another. ${ }^{146}$ This law should be made to apply for American Negroes. The payment should be in the form of a massive program by the Government of special compensatory measures which could be regarded as a settlement in accordance with the accepted practice of common law. Such measures would certainly be less expensive than any computation based on two centuries of unpaid wages and accumulated interest." 147

In his 1967 testimony before the Kerner Commission, six months before his murder, Dr. King read into the record this section from Why We Can't Wait, again proposing massive government programs in the areas of education, health care, employment and housing, justified by the principle of reparations for the appropriation of labor taken from Black Americans. ${ }^{148}$

\footnotetext{
${ }^{145}$ Martin Luther King, Jr., Speech at the Historic March on Washington: I Have a Dream, supra note 142, at 1 (emphasis added).

${ }^{146} \mathrm{Dr}$. King describes this as a common law principle, but it is better described as the equitable remedy of restitution.

${ }^{147}$ Martin Luther King, JR., Why We Can'T Wait, supra note 103, at 137.

${ }^{148}$ See Martin Luther King, Jr., Statement to the National Advisory Commission on Civil Disorders, supra note 104 , at 8.
} 
It is my great feeling that a massive program must be developed by the federal government to bring new hope into being. Among the many vital jobs to be done, the Nation must not only radically readjust its attitude toward the Negro and the compelling present, but must incorporate in its planning some compensatory consideration for the handicaps he has inherited from the past. It is impossible to create a formula for the future which does not take into account that our society has been doing something special against the Negro for hundreds of years. ${ }^{149}$

Dr. King then told the Commission the story of his conversation with Prime Minister Nehru, in which Nehru explained why members of lower castes were given preferences in university admissions and public employment, and that if it was discrimination it was nonetheless justified as an act of atonement. King testified:

America must seek its own way of atoning for the injustices she has inflicted on her Negro citizens [not for] atonement's sake, ... [but as a] way to bring the Negro standard to a realistic level. ... . The moral justification for special measures for Negroes is rooted in the robberies inherent in the institution of slavery. ${ }^{150}$

It is thus clear that Dr. King, in supporting race-conscious affirmative action-type special measures to address the problem of racial inequality, alongside programs to address the related and overlapping problem of endemic poverty, relied on the principle of restitution for slavery and racial discrimination/oppression, itself a theory of reparations, as the legal and moral justification.

\section{Dr. King, Latinx Leaders, and California's Battle over Proposition 209}

In the last years before his life was cut short, Dr. King sent several telegrams to César Chávez, the leader of the United Farm Workers and a celebrated leader within the Latinx community. Dr. King expressed unity with the farm workers' movement happening in California as well as a desire to meet and work together "[a]s brothers in the fight for equality." 151

In a 1966 message to Chávez, Dr. King made it clear that theirs was a shared goal to correct historical wrongs:

As brothers in the fight for equality, I extend the hand of fellowship and good will and wish continuing success to you and your members. The fight for equality must be fought on many fronts in the urban slums, in the sweat shops of the factories and fields.

${ }^{149}$ Id. at 4-5.

${ }^{150}$ Id. at 6.

151 See Telegram from Martin Luther King, Jr., supra note 29. 
Our separate struggles are really one - a struggle for freedom, for dignity and for humanity. You and your valiant fellow workers have demonstrated your commitment to righting grievous wrongs forced upon exploited people. We are together with you in spirit and in determination that our dreams for a better tomorrow will be realized. ${ }^{152}$

In another telegram, Dr. King commended Chávez's use of hunger strikes and highlighted their shared commitment to a Gandhian tradition of non-violence:

I am deeply moved by your courage in fasting as your personal sacrifice for justice through nonviolence. Your past and present commitment is eloquent testimony to the constructive power of nonviolent action and the destructive impotence of violent reprisal. You stand today as a living example of the Ghandian [sic] tradition with its great force for social progress and its healing spiritual powers. . . The plight of your people and ours is so grave that we all desperately need the inspiring example and effective leadership you have given. ${ }^{153}$

Just before he was murdered, Dr. King again telegrammed Chávez his plan to visit migrant labor camps in California during the Poor People's Campaign. ${ }^{154}$ Nevertheless, these telegrams illuminate Dr. King's influence on Chávez and the farm workers' movement, from carrying out Gandhian principles of non-violence to a shared fight for the equality of exploited peoples.

Nearly a generation later, in the mid-1990s, Latinx leaders in California played leading roles in fighting against the California Civil Rights Initiative (CCRI) - or, Proposition 209 - a ballot initiative that would ban affirmative action in public education, contracting and employment. Leaders opposing Proposition 209 included Harry Pachon, president of the Tomás Rivera Research Center, ${ }^{155}$ Elizabeth Toledo, then president of the National Organization for Women in California (NOW), ${ }^{156}$ Martha Jiménez, a lead MALDEF lawyer in San Francisco, ${ }^{157}$ Gloria Molina, member of the Los

$152 \mathrm{Id}$

${ }^{153}$ Telegram from Martin Luther King, Jr. to Cesar Chaves [sic] (Mar. 5, 1968), http:// www.thekingcenter.org/archive/document/telegram-mlk-cesar-chavez, archived at https://per ma.cc/JLN4-VR6B.

${ }^{154}$ Martin L. Deppe, Operation Breadbasket: An Untol.d Story of Civil. Rights in Chicago 1966-1971 152 (2017).

155 Lydia Chávez, The Color Bind: Califfornia's Battle to End Affirmative ACTION 88-89 (1998).

${ }^{156} \mathrm{Id}$. at 95 .

${ }^{157} \mathrm{Id}$. at $102-03$. 
Angeles County Board of Supervisors, ${ }^{158}$ and Dolores Huerta, labor leader and co-founder of United Farm Workers with César Chávez. ${ }^{159}$

\section{Conclusion}

The unifying theme in Dr. King's advocacy was inclusiveness of all potential remedies for inequality. When we examine the body of his work, and particularly his writings, sermons, speeches and public testimony, this becomes clear. Here again, if we examine the less-often cited portion of his iconic 1963 I Have A Dream speech, where he called for reparations; his 1964 book, Why We Can't Wait, and his 1965 Independence Day sermon at his Atlanta church, where he invoked Indian affirmative action ("reservations") and called for American affirmative action; and his 1967 testimony before the Kerner Commission, where he invoked Indian reservations and called for reparations and race and class-based affirmative action, what emerges is a powerful call for both race and class-based affirmative action. Any assertion that Dr. King was an opponent of race-conscious affirmative action must rely solely on a single phrase in a single speech, and avoid his long-standing commitment to race-conscious affirmative action in his speeches, writings and - most importantly - his actions. But neither should we conclude that he opposed class-based approaches to affirmative action; he supported both forms, to be used in tandem.

As we continue to debate the costs and benefits of affirmative action, Dr. King's views are likely to continue to be invoked. Those who support race-conscious affirmative action as a remedy for past and continuing racism can find much in Dr. King's words and deeds to support their arguments. Those who support class-based affirmative action as a social response to endemic poverty and lack of social mobility can also find much in his speeches and activism to support their view, as long as it is combined with race-conscious affirmative action. But those who rely on a small selection of Dr. King's I Have a Dream speech, or other speeches or writings where he expressed the hope that the disease of racism would someday be cured, should be admonished for their use of his words taken entirely out of context. Dr. King's support for affirmative action-type programs based on both race and class was unquestionable.

${ }^{158}$ Sonia Nazario, Celebrities Urge Defeat of Prop. 209, L.A. Times (Oct. 28, 1996), http://articles.latimes.com/1996-10-28/news/mn-58696_1_government-affirmative-action, archived at https://perma.cc/DWG7-AQRR.

${ }^{159} \mathrm{Id}$. Huerta was featured in a radio spot, organized by the Feminist Majority and NOW, opposing Proposition 209. The transcription reads: "I am Dolores Huerta, co-founder of the United Farmworkers. Proposition 209 is a lie. It aims to take away our civil rights. It aims to close the doors of opportunity that have opened for us. ... Many people gave their lives so that we could better ourselves - César Chávez, Rubén Salazar; Together, we can defeat this Proposition 209. Sí Se Puede!" Chávez, supra note 155, at 230. 